\section{HSE}

Historia Social y de la Educación

Social and Education History
Hipatia Press

www.hipatiapress.com

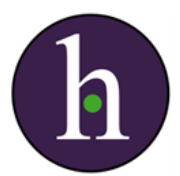

Instructions for authors, subscriptions and further details:

$\underline{\text { http://hse.hipatiapress.com }}$

\title{
Espiritistas y Librepensadoras
}

Ginés Puente Pérez ${ }^{1}$

1) Universitat Rovira i Virgili (Spain)

Date of publication: October $23^{\text {rd }}, 2018$

Edition period: Edition period: October 2018-February 2019

To cite this article: Puente, G. (2018). Espiritistas y Librepensadoras [Review of the book]. Social and Education History 7(3), 304-308. doi: 10.17583/hse.2018.3646

To link this article: http://dx.doi.org/10.17583/hse.2018.3646

PLEASE SCROLL DOWN FOR ARTICLE

The terms and conditions of use are related to the Open Journal System and to Creative Commons Attribution License (CC-BY). 


\section{Reviews (I)}

Marín, D. (2018). Espiritistes i Lliurepensadores: dones pioneres en la lluita pels drets civils, Barcelona: Angle Editorial.

4

1 libro de Dolors Marín Espiritistes $i$ Llibrepensadores, publicado en catalán este 2018 por Angle Editorial, es un ensayo imprescindible para entender los orígenes de las vindicaciones de las mujeres, desde los inicios del siglo XIX hasta las primeras décadas del XX.

A nivel historiográfico se ha producido un largo silencio sobre este tema. Si bien son muchos los estudios que se han encargado de explicar los orígenes de los movimientos obreros, del librepensamiento y del espiritismo (Horta, 2004 y 2001; Palà, 2018 y Termes, 2011), así como de hacer relatos de vida de algunas de las protagonistas políticas - Teresa Claramunt (Pradas Baena, 2006 y Vicente, 2006), Isabel Vila (Ferrer y Gironès, 1996) o Teresa Mañé (Marín y Palomar, 2006; Puente, 2016; Vadillo, 2013)—, no son tantos los que se encargan de entender la relevancia y trascendencia que estas mujeres tuvieron en la configuración de los nuevos modelos públicos y privados.

Precisamente, el interés de la autora hacia este tema nace de un estudio, iniciado hace más de cinco años, con la intención de reconstruir la historia de las mujeres vinculadas con los orígenes del anarcosindicalismo. La relación entre todas ellas aparece a través de la entidad La Progresiva Femenina, una de las primeras asociaciones de carácter feminista que consiguió aglutinar a mujeres anarquistas como la ya mencionada Teresa Claramunt-, republicanas - como Ángeles López de Ayala - y espiritistas — como la Amalia Domingo Soler. Pero ¿Cómo podía haber mujeres de ideologías tan diferentes 
HSE - Social and Education History Vol. 7 No. 3 October 2018 pp. 304-308

en una misma entidad? ¿Cuál fue el sentido de sus vindicaciones? Es precisamente a raíz de estas preguntas que nace el proyecto de esta monografía.

La obra recoge la historia de vida de una veintena de mujeres que lucharon contra el sistema religioso de su época, contra todo aquello que supuso un problema por su acceso a la educación y por todo lo que impidió el acceso de las mujeres a los ámbitos públicos. Estas mujeres fueron capaces de crear nuevas cabeceras de diarios, constituir entidades femeninas, hacer actos públicos multitudinarios, fundar escuelas laicas, rechazar el sistema de levas, etc.

Marín nos introduce en un mundo donde las mujeres pasaron de firmar sus trabajos con pseudónimos de hombres, a empezar a hacerlo con pseudónimos de mujeres y con sus nombres de pila. Mujeres que editaron y participaron en publicaciones como Luz del Porvenir, $\mathrm{La}$ Conciencia Libre, Luz de Unión, Las Dominicales del Librepensamiento o El Gladiador. Un tejido de más de 25 publicaciones en todo el Estado español que pronto se extenderían por América Latina, entre otros lugares del planeta.

En España el centro más importante espiritista y librepensador fue Barcelona. De hecho, según la autora, el espiritismo es un fenómeno esencialmente urbano relacionado al proletariado industrial femenino y al mundo que lo rodea. Es por este motivo que también se formaron núcleos en Alicante, Cádiz, Madrid o Zaragoza. Las espiritistas, que veían la Iglesia Católica como una institución envejecida principalmente por su relación con las mujeres, abrazaron la idea de la transmigración de las almas, importada desde los Estados Unidos. Todas estas teorías popularizadas por las hermanas Kate y Margaret Fox y, principalmente, por Allan Kardec, se generaron como una nueva ciencia que se popularizó a través de prácticas culturales. Unas prácticas que intentaron conectar con familiares difuntos.

Dolors Marín observa y propone que los movimientos espiritistas configuran una entidad propia más allá del resto de corrientes de 
pensamiento que aparecen en el periodo señalado. Aun así, la autora refiere que en los espacios ocupados a partir de la segunda mitad del XIX participaron personajes que transitaban ideologías muy diversas que, en general, tuvieron un objetivo común: el anticlericalismo y la transformación de la sociedad.

La monografía se divide en tres apartados. El primero se centra en escritoras seguidoras del socialismo utópico y, más concretamente, de Charles Fourier. Véase: Zoé de Gamond, Cándida Sanz, Matilde Fernández, Matilde Alonso Gainza o Maria Trullos.

Gamond (1806-1854) fue la primera mujer que realizó una síntesis del pensamiento de Fourier y, por lo tanto, del socialismo utópico a raíz de la obra Explanación del sistema societario, publicada el 1841 (Marín, 2018, p. 27). Aquel mismo año, aparecía en la península una obra de Jan Czinski titulada El porvenir de las mujeres, precedido de un texto feminista de Margarita López de Morla y Virués. Este libro muestra la difusión de un ideario político y social que estableció una base teórica para la emancipación de las mujeres y del modelo de sociedad que se quería construir.

El segundo bloque de la obra hace una aproximación al asociacionismo femenino mediante un análisis de La Sociedad Progresiva Femenina y La Sociedad Autónoma de Mujeres, sociedades que influencian directamente a la sociedad catalana y española de finales del XIX y primeras décadas del XX. A continuación, en este segundo bloque, se recuperan los relatos biográficos de Amalia Domingo Soler, Júlia Aymà, Isabel Vilà, Isabel Zwonar, Teresa Claramunt, Ângeles López de Ayala o María Marín. Mujeres, todas ellas que, desde ideologías diferentes, participaron en proyectos comunes.

Por último, el tercer apartado, habla de aquellas mujeres que, no tan activas públicamente como las primeras o las segundas, harán un trabajo no menos importante en ámbitos como la pedagogía o la teosofía. Entre ellas: Carmen Mateos, Josefina Maynadé, María Solà y Emilia Vilalta.

El único inconveniente que presenta el libro, que a su vez puede observarse como virtud, es la carencia de notas al pie. Si bien este 
HSE - Social and Education History Vol. 7 No. 3 October 2018 pp. 304-308

hecho hace la lectura mucho más ágil, a nivel académico se echan de menos referencias con las que acercarnos a la bibliografía y a la documentación que se recogen al final del libro.

En definitiva, la obra de Dolors Marín es un libro necesario no sólo por su interés científico y divulgativo sino también porque en un periodo en que los feminismos vuelven a tener protagonismo, observar y entender la antesala de estos movimientos se convierte en un elemento de interés. Entenderlo hace que el camino que iniciaron todas estas mujeres no sea en vano. Cómo dice la autora: "Una ciudad sin memoria es una ciudad muerta".

\section{Referencias}

Ferrer i Gironès, F. (1996). Isabel Vilà i Pujol. La primera sindicalista catalana, Llagostera: Ajuntament.

Horta, G. (2001). De la mística a les barricades. Introducció a l'espiritisme català del XIX dins el context ocultista europeu, Barcelona: Editorial Proa.

Horta, G. (2004). Cos i revolució. L'espiritisme català o les paradoxes de la modernitat, Barcelona: Edicions de 1984.

Marín, D. (2018). Espiritistes i Lliurepensadores: dones pioneres en la lluita pels drets civils, Barcelona: Angle Editorial.

Marín, D. y Palomar, S. (2006). Els Montseny-Mañé, un laboratori d'idees, Reus: Arxiu Municipal-Carrutxa.

Palà, A. (2018). Viure l'anticlericalisme: una història cultural del lliure pensament català (1868-1923), Barcelona: Editorial afers Catarroja.

Pradas Baena, M.A. (2006). Teresa Claramunt, la "virgen roja" barcelonesa: biografía y escritos. Barcelona: Virus.

Puente, G. (2016). De Soledad Gustavo a Teresa Mañé (1865-1939), (Treball Final de Màster). Màster en estudis de Dones, Gènere i Ciutadania, Barcelona. 


$$
\text { HSE - Social and Education History, 7(3) } 309
$$

Termes, J. (2011). Historia del anarquismo en España (1870-1980), Barcelona: RBA Libros.

Vadillo, J. (2013). Abriendo brecha: los inicios de la lucha de las mujeres por su emancipación. El ejemplo de Soledad Gustavo, Madrid: Volapük Ediciones.

Vicente, L. (2006). Teresa Claramunt. Pionera del feminismo obrerista anarquista, Madrid: FAL.

Ginés Puente Pérez

Universitat de Barcelona ginespuenteperez@gmail.com 